\title{
Nutrient intake assessed with Diet History Questionnaire II, in relation to long-term calcium-phosphate control in hemodialysis patients with end-stage renal failure
}

\author{
Katarzyna Wyskidaa, A-F, Jarosław Wajda 2, B, Dariusz Klein 3, 4, B, Joanna Witkowicz, B, Rafał Ficek ${ }^{6, B}$, \\ Sylwia Rotkegel ${ }^{7, B}$, Urszula Spiechowicz-Zaton' ${ }^{8, B}$, Joanna Kocemba-Dyczek ${ }^{9,10, B}$, Jarosław Ciepał 11, B, \\ Magdalena Olszanecka-Glinianowicz ${ }^{1, C-F}$, Andrzej Więcek ${ }^{6, E, F}$, Jerzy Chudek ${ }^{7,12, ~ A, ~ C-F ~}$ \\ ${ }^{1}$ Health Promotion and Obesity Management Unit, Department of Pathophysiology, \\ 7 Dialysis Center in Katowice, Centrum Dializa Sp. z 0.0., Poland \\ Medical University of Silesia, Poland \\ 2 Dialysis Center, Provincial Specialist Hospital No. 3 in Rybnik, Poland \\ ${ }^{3}$ Dialysis Center in Tychy, Centrum Dializa Sp. z 0.0., Poland \\ ${ }^{4}$ Dialysis Center in Pszczyna, Centrum Dializa Sp. z 0.0., Poland \\ ${ }^{5}$ Dialysis Center in Siemianowice Śląskie, Nefrolux, Poland \\ ${ }^{6}$ Department of Nephrology, Transplantation and Internal Medicine, \\ 8 Dialysis Center in Chorzów, Centrum Dializa Sp. z 0.0., Poland \\ ${ }^{9}$ Dialysis Center in Żory, Centrum Dializa Sp. z 0.0., Poland \\ ${ }^{10}$ Dialysis Center in Wodzisław Śląski, Centrum Dializa Sp. z 0.0., Poland \\ ${ }^{11}$ Dialysis Center in Sosnowiec, Centrum Dializa Sp. z 0.0., Poland \\ ${ }^{12}$ Department of Internal Medicine and Oncological Chemotherapy, Medical \\ University of Silesia, Katowice, Poland
} Medical University of Silesia, Poland

A - research concept and design; $B$ - collection and/or assembly of data; $C$ - data analysis and interpretation;

$D$ - writing the article; $E$ - critical revision of the article; $F$ - final approval of the article

Address for correspondence

Katarzyna Wyskida

E-mail:kasiawys@gmail.com

\section{Funding sources}

Supported by the grant from the Medical

University of Silesia (No. KNW-2-028/D/4/N)

Conflict of interest

None declared

Received on June 4, 2016

Reviewed on July 12, 2016

Accepted on November 15, 2016

DOI

10.17219/acem/67050

Copyright

Copyright by Author(s)

This is an article distributed under the terms of the Creative Commons Attribution Non-Commercial License

(http://creativecommons.org/licenses/by-nc-nd/4.0/)

\section{Abstract}

Background. Diet is a key factor that determines proper alignment of calcium-phosphate and nutritional status among hemodialysis (HD) patients.

Objectives. To assess the nutrient intake in relation to long-term calcium-phosphate control in HD patients with end-stage renal failure.

Material and methods. The study included 107 patients ( 66 men, 41 women) from 10 dialysis centers in the Upper Silesia region of Poland. To analyze the diet composition during the previous year, a portion-sized version of the Diet History Questionnaire II (DHQ-II) from National Institutes of Health was used. The nutrient intake was assessed in accordance with the most complex recommendations on HD patients' nutrition - K/DOQI Clinical Practice Guidelines for nutrition in chronic renal failure. Poor long-term alignment of calcium-phosphate homeostasis was defined as the presence of over $50 \%$ monthly phosphorus concentrations exceeding $5 \mathrm{mg} / \mathrm{dL}$, and for calcium $10.2 \mathrm{mg} / \mathrm{dL}$, during the last 6-month period.

Results. Lower than recommended protein intake was found in $63 \%$ of HD patients (average consumption: $0.9 \pm 0.5 \mathrm{~g} / \mathrm{kg} / \mathrm{day})$. Most of the patients consumed too much fat ( $33.5 \pm 6.7 \%$ of daily energy intake) and sodium ( $2912 \pm 1542 \mathrm{mg} / \mathrm{day})$. In 42\% of patients, dietary phosphorus intake was consistent with the recommendations (13.3 $\pm 7.5 \mathrm{mg} / \mathrm{kg} /$ day). Protein intake over $1.2 \mathrm{~g} / \mathrm{kg} /$ day resulted in an increased consumption of phosphorous, but did not increase the risk of misalignment of phosphorus concentrations $(O R=1.15$ [0.40-3.27]); $p=0.8)$. Poor control of serum phosphorus concentrations was observed in $69 \%$ of patients (they were on average 8 years younger). The average intake of protein and phosphate in the groups with good or not satisfactory serum phosphorus alignment did not differ significantly.

Conclusions. Adequate control of protein intake is not sufficient to obtain phosphorus alignment, especially in younger $\mathrm{HD}$ patients.

Key words: diet, hemodialysis, food frequency questionnaire, calcium-phosphate control, nutrient intake 


\section{Introduction}

Cardiovascular disease is the most common cause of death in patients with end-stage kidney disease (ESKD) on renal replacement therapy. Epidemiological studies have shown that one of the major causes of increased morbidity and mortality in this group of patients are the disturbances of the calcium-phosphate metabolism. ${ }^{1}$ Diet is a key factor that determines both calcium-phosphate balance and nutritional status in hemodialysis (HD) patients, and is an essential component of the therapeutic approach in this population. $^{2}$

The primary role of diet in the non-dialysis stage of chronic kidney disease (CKD) is to reduce uremic toxemia and to diminish the risk of developing renal osteodystrophy and hyperkalemia. This includes a restriction of daily protein intake up to $0.6-0.75 \mathrm{~g} / \mathrm{kg}$ of body mass, and food rich in phosphorus additives. Nutritional recommendations change considerably after the initiation of dialysis. Due to an increased risk of developing protein-energy malnutrition, higher daily protein intake is recommended (1.2 g/kg body mass/day), while maintaining the dietary phosphate restriction (Table 1). ${ }^{3,4}$

A low-phosphate diet is difficult to follow for a long period of time, as most nourishment with high protein content (products of animal origin, e.g., meat and dairy products) are also a rich source of phosphorus. This often complicates the choice of food, leading to monotony of the diet, and consequently a lack of acceptance of the recommendations by numerous patients. ${ }^{5}$

The basic criterion for good calcium-phosphate control, in accordance with the recommendations of the Working Group of the Polish Society of Nephrology on the quality of treatment in hemodialysis ESKD patients, is obtaining proper values of serum concentrations of calcium (8.4-10.2 $\mathrm{mg} / \mathrm{dL})$ and phosphorus (2.5-5.0 $\mathrm{mg} / \mathrm{dL})$. The concentration of native (intact) parathyroid hormone (PTH) should be in the range of 2-9 times the upper limit of the reference kit $(\sim 130-600 \mathrm{pg} / \mathrm{mL}){ }^{6}$ It should be emphasized that there are some discrepancies between Polish recommendations and the latest (2009) Kidney Disease: Improving Global Outcomes (KDIGO) CKD-MBD Work Group clinical practice guidelines for the diagnosis, evaluation, prevention, and treatment of chronic kidney disease - mineral and bone disorder, and older (2003) National Kidney Foundation Kidney Disease Outcomes Quality Initiative (NKF K/DOQI) guidelines on bone metabolism and disease in chronic kidney disease. ${ }^{7,8}$ KDIGO guidelines do not give specific reference ranges of calcium, phosphorus, and intact PTH levels. They emphasize the role of trends in laboratory values on therapeutic decision-making, and recommend that clinical laboratories should inform clinicians on the actual method used and report any change in the assays. According to K/DOQI recommendations, serum levels of phosphorus should be maintained between $3.5 \mathrm{mg} / \mathrm{dL}$ and $5.5 \mathrm{mg} / \mathrm{dL}$, serum levels of corrected total
Table 1. Recommended energy, macro- and micronutrient intake in HD patients (in accordance with K/DOQI recommendations $\left(^{*}\right.$ ) or EBPG on nutrition $(\dagger))^{11,12}$

\begin{tabular}{|c|c|}
\hline $\begin{array}{l}\text { Macronutrient } \\
\text { intake }\end{array}$ & Recommended intake \\
\hline Protein intake ${ }^{a}$ & $\begin{array}{c}1.2 \mathrm{~g} / \mathrm{kg} \text { body mass/day ( } \geq 1.2-1.3 \mathrm{~g} / \mathrm{kg} \text { body } \\
\text { mass/day for patients who are actually ill or have } \\
\text { more severe protein-energy wasting)* } \\
\text { at least } 1.1 \mathrm{~g} / \mathrm{kg} \text { ideal body mass/day in clinically } \\
\text { stable chronic HD patients }{ }^{\dagger}\end{array}$ \\
\hline Energy intake ${ }^{b}$ & $\begin{array}{c}35 \mathrm{kcal} / \mathrm{kg} \text { body mass/day for those who } \\
\text { are }<60 \text { years of age and } 30-35 \mathrm{kcal} / \mathrm{kg} \text { body } \\
\text { mass } / \text { day for individuals of } 60 \text { years or older* } \\
30-40 \mathrm{kcal} / \mathrm{kg} \text { ideal body mass/day, adjusted to } \\
\text { age, gender, and to the best estimate of physical } \\
\text { activity level }^{+}\end{array}$ \\
\hline Fat intake & $30 \%$ of daily energy intake* \\
\hline Saturated fat & up to $10 \%$ of daily energy intake* \\
\hline $\begin{array}{l}\text { Polyunsaturated } \\
\text { fatty acids }\end{array}$ & up to $10 \%$ of daily energy intake* \\
\hline $\begin{array}{l}\text { Monounsaturated } \\
\text { fatty acids }\end{array}$ & up to $20 \%$ of daily energy intake* \\
\hline Carbohydrates $^{c}$ & the rest of non-protein calories* \\
\hline Total fiber & $20-25 \mathrm{~g} / \mathrm{day}^{*}$ \\
\hline Sodium & $\begin{array}{l}750-2000 \mathrm{mg} / \mathrm{day}^{*} \\
\leq 2000-2300 \mathrm{mg} \text { of sodium or } 5-6 \mathrm{~g}(75 \mathrm{mg} / \mathrm{kg} \\
\text { body mass)/day of sodium chloride }{ }^{+}\end{array}$ \\
\hline Potassium & $\begin{array}{c}\text { up to } 70-80 \mathrm{mEq} / \text { day }^{*} \\
50-70 \mathrm{mmol}(1950-2730 \mathrm{mg} \text { ) or } 1 \mathrm{mmol} / \mathrm{kg} \text { ideal } \\
\text { body mass in patients with pre-dialysis serum } \\
\text { potassium }>6 \mathrm{mmol} / \mathrm{L}^{\dagger}\end{array}$ \\
\hline Phosphorus & $\begin{array}{c}10-17 \mathrm{mg} / \mathrm{kg} \text { body mass/day* } \\
\text { 800-1000 } \mathrm{mg}^{+}\end{array}$ \\
\hline Calcium ${ }^{d}$ & $\begin{array}{l}\leq 1000 \mathrm{mg} / \text { day }^{*} \\
\leq 2000 \mathrm{mg} / \text { day }^{\dagger}\end{array}$ \\
\hline Magnesium & 200-300 mg/day* \\
\hline Iron & $\begin{array}{c}\text { requirements vary according to the dose } \\
\text { of administered erythropoietin* } \\
8 \mathrm{mg} / \text { day for men, and } 15 \mathrm{mg}^{*} \text { day for women } \\
\text { is recommended }{ }^{\dagger}\end{array}$ \\
\hline Zinc & $\begin{array}{c}15 \mathrm{mg} / \mathrm{day}^{*} \\
\text { 8-12 mg/day of elemental zinc for women, } \\
\text { and } 10-15 \mathrm{mg} / \text { day for } \text { men }^{\dagger}\end{array}$ \\
\hline
\end{tabular}

EBPG - European Best Practice Guidelines; ${ }^{\text {a }}$ minimum of $50 \%$ of total protein intake should be derived from high-quality protein; ${ }^{b}$ in overweight or obese patients, limitation of total energy intake is recommended in order to reduce weight; ' preferably complex carbohydrates; ${ }^{\text {d }}$ both dietary calcium intake and oral calcium-based phosphate binders.

calcium within the normal range for the laboratory, preferably toward the lower limit (8.4-9.5 $\mathrm{mg} / \mathrm{dL})$, and the target range of plasma levels of intact PTH in dialysis patients should be of $150-300 \mathrm{pg} / \mathrm{mL} .{ }^{8}$

The percentage of patients with hyperphosphatemia in dialysis units, according to the Working Group of the Polish Society of Nephrology, should be less than $45 \%{ }^{6}$ Serum calcium should be definitely below $10.2 \mathrm{mg} / \mathrm{dL}$, as greater values have been related to increased mortality in HD patients. ${ }^{7,9}$ 
There is a lack of data regarding the percentage of HD patients that follow the recommended levels of macroand micronutrients in their diet. Therefore, the aim of the study was to assess nutrient intake in relation to long-term calcium-phosphate control in hemodialysis ESKD patients.

\section{Material and methods}

\section{Study population and data collection}

The study population consisted of 107 patients (66 males, 41 females) from 10 dialysis centers in the Upper Silesia Region of Poland undergoing hemodialysis 3 times per week in morning sessions, who had been on HD therapy for at least 6 months and who gave written consent for participation in this study. Among the exclusion criteria were gastrointestinal tract diseases and current hospitalization. The study protocol was approved by the Bioethical Committee of the Medical University of Silesia in Katowice (KNW 22/KB1/185/I/11/12). Figure 1 shows a flow chart of the study.

Clinical and laboratory data was retrieved from the medical records of the dialysis centers. Residual renal function was assessed on the basis of residual diuresis reported by the patients.

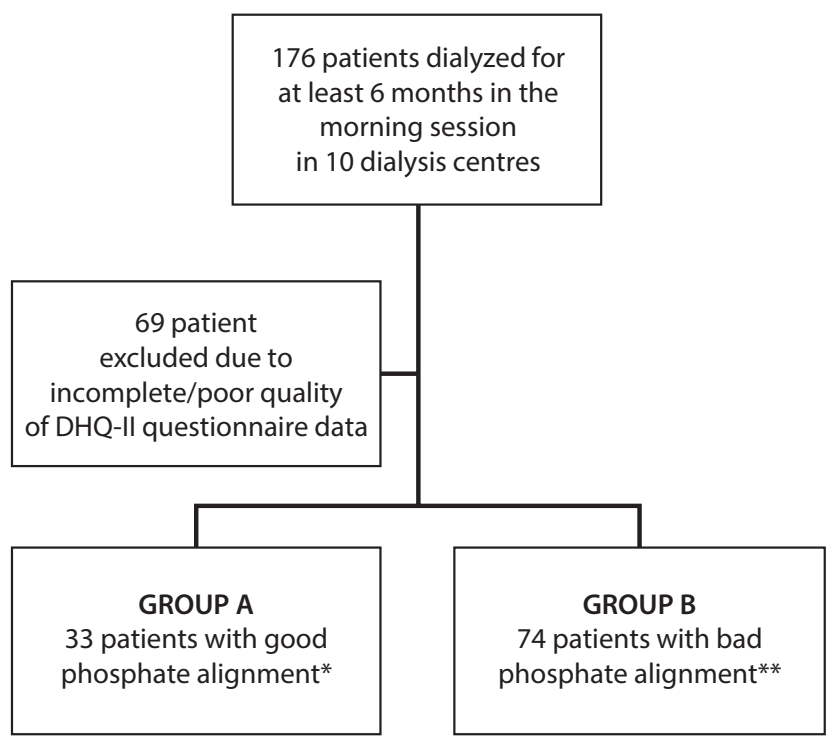

Fig. 1. Flow chart of the study

${ }^{*}<50 \%$ monthly phosphorus levels $\geq 5 \mathrm{mg} / \mathrm{dL} ;{ }^{* *} \geq 50 \%$ monthly phosphorus levels $\geq 5 \mathrm{mg} / \mathrm{dL}$.

\section{Diet assessment}

To analyze the composition of patient diet during the previous year, a portion-size version of the food frequency questionnaire by the National Institutes of Health - Diet History Questionnaire II (DHQ-II) was used. ${ }^{10}$ Patients were instructed on how to complete the questionnaire, and written instructions were provided. The analysis of the survey was performed using the computer program Diet Calc (National Cancer Institute, Bethesda, USA), and adopted as the standard value in accordance with the most complex recommendations on HD patients' nutrition K/DOQI Clinical Practice Guidelines for nutrition in chronic renal failure (Table 1). ${ }^{11}$ Consumption of energy, protein and phosphorus was expressed per kilogram of current body mass. ${ }^{7}$ Other nutrient intake (carbohydrates and fats) was presented as total daily intake and percentage of daily energy. Nutritional status was assessed on the basis of anthropometric measurements (body mass and height) used to calculate body mass index (BMI; $\mathrm{kg} / \mathrm{m}^{2}$ ), stratified in line with WHO recommendations for Caucasians.

\section{Analysis of calcium-phosphate parameter alignment}

To evaluate the parameters of the calcium-phosphate metabolism, the results of monthly routine assessments of phosphorus, calcium, and iPTH concentrations were used. These included results from the last 6 months preceding the analysis of the diet. Recommended daily doses of oral phosphate binding drugs (calcium carbonate and sevelamer hydrochloride) were incorporated. The criterion of bad calcium-phosphate alignment was the occurrence of phosphorus concentrations exceeding $5 \mathrm{mg} / \mathrm{dL}$, and calcium over $10.2 \mathrm{mg} / \mathrm{dL}$ in $\geq 50 \%$ of monthly assessments (according to the recommendations of the working group of the Polish Society of Nephrology concerning the quality criteria of dialysis in ESKD patients). ${ }^{6}$

\section{Statistical analysis}

For the statistical analysis, Statistica software v. 11.0 (StatSoft Inc., Tulsa, USA) was used. Data was presented as mean values \pm standard deviation. The distribution of the examined variables was checked by Shapiro-Wilk test. Categorical variables were compared using $X^{2}$ tests, while quantitative variables with ANOVA or Mann-Whitney $\mathrm{U}$ test, as appropriate. Logistic regression was used to calculate odds ratios (OR). The threshold for statistical significance was set at $\alpha=0.05$. The statistical review of the study was performed by a biomedical statistician.

\section{Results}

\section{Overall characteristics of patients}

Detailed patient characteristics, including anthropometric data, causes of CKD, concomitant diseases, dialysis parameters, pharmacotherapy, and the degree of calciumphosphate alignment is shown in Table 2. 
Table 2. Patients' characteristics, mean \pm SD (group A - patients with $<50 \%$ monthly phosphorus levels $\geq 5 \mathrm{mg} / \mathrm{dL}$; group $B$ - patients with $\geq 50 \%$ monthly phosphorus levels $\geq 5 \mathrm{mg} / \mathrm{dL}$ )

\begin{tabular}{|c|c|c|c|c|}
\hline Variables & $\begin{array}{l}\text { All patients } \\
(\mathrm{n}=107)\end{array}$ & $\begin{array}{l}\text { Group A } \\
(n=33)\end{array}$ & $\begin{array}{l}\text { Group B } \\
(n=74)\end{array}$ & $\mathrm{p}$-value \\
\hline Gender [male/female] & $66 / 41$ & $19 / 14$ & $47 / 27$ & ns \\
\hline Age [years] & $61.9 \pm 14.8$ & $67.4 \pm 12.5$ & $59.4 \pm 15.2$ & $p<0.01$ \\
\hline Body mass [kg] & $73.0 \pm 15.0$ & $74.8 \pm 14.1$ & $72.5 \pm 15.4$ & ns \\
\hline Height [m] & $1.68 \pm 0.08$ & $1.69 \pm 0.07$ & $1.67 \pm 0.09$ & ns \\
\hline $\begin{array}{l}\text { BMI }\left[\mathrm{kg} / \mathrm{m}^{2}\right] \\
\text { underweight }[\mathrm{n}(\%)] \\
\text { normal weight }[\mathrm{n}(\%)] \\
\text { overweight }[\mathrm{n}(\%)] \\
\text { obesity }[\mathrm{n}(\%)] \\
\text { I grade obesity [n (\%)] } \\
\text { II grade obesity [n (\%)] }\end{array}$ & $\begin{array}{c}26.1 \pm 4.8 \\
2(1.9) \\
46(43.0) \\
38(35.5) \\
21(19.6) \\
15(14.0) \\
6(5.6)\end{array}$ & $\begin{array}{l}26.3 \pm 4.4 \\
0 \\
14(42.4) \\
12(36.4) \\
7(21.1) \\
6(18.2) \\
1(3.0)\end{array}$ & $\begin{array}{l}26.0 \pm 5.0 \\
2(2.7) \\
32(43.2) \\
26(35.1) \\
14(18.8) \\
9(12.2) \\
5(6.8)\end{array}$ & ns \\
\hline Time on dialysis [months] & $53 \pm 52$ & $35 \pm 32$ & $61 \pm 58$ & $p<0.01$ \\
\hline Kidney transplantation [n] & 9 & 0 & 9 & \\
\hline $\begin{array}{l}\text { Renal failure cause } \\
\text { diabetes [n] } \\
\text { hypertension [n] } \\
\text { nephrolithiasis [n] } \\
\text { glomerulonephritis [n] } \\
\text { interstitial nephritis [n] } \\
\text { ADPKD [n] } \\
\text { vasculitis [n] } \\
\text { ischemia [n] } \\
\text { other or unknown [n] }\end{array}$ & $\begin{array}{c}31 \\
12 \\
6 \\
15 \\
6 \\
9 \\
3 \\
2 \\
23\end{array}$ & $\begin{array}{l}10 \\
6 \\
4 \\
2 \\
0 \\
2 \\
1 \\
1 \\
7\end{array}$ & $\begin{array}{c}21 \\
6 \\
2 \\
14 \\
4 \\
7 \\
2 \\
1 \\
16\end{array}$ & \\
\hline $\begin{array}{l}\text { Co-morbidities } \\
\text { hypertension [n (\%)] } \\
\text { ischemic heart disease [n (\%)] } \\
\text { myocardial infarction [n (\%)] } \\
\text { stroke [n (\%)] } \\
\text { diabetes [n (\%)] } \\
\text { hypercholesterolemia [n (\%)] } \\
\text { parathyroidectomy [n (\%)] } \\
\text { cancer [n (\%)] } \\
\text { PCI [n (\%)] } \\
\text { CABG [n (\%)] }\end{array}$ & $\begin{array}{c}99(92.5) \\
57(53.3) \\
20(18.7) \\
6(5.6) \\
40(37.4) \\
25(23.4) \\
6(5.6) \\
17(15.9) \\
9(8.4) \\
7(6.5)\end{array}$ & $\begin{array}{c}33(100) \\
24(72.7) \\
8(24.2) \\
3(9.1) \\
14(42.4) \\
10(30.3) \\
2(6.1) \\
6(18.2) \\
1(3.0) \\
4(12.1)\end{array}$ & $\begin{array}{c}66(89.2) \\
33(44.6) \\
12(16.2) \\
3(4.1) \\
26(35.1) \\
15(20.3) \\
4(5.4) \\
11(14.9) \\
8(10.8) \\
3(4.1)\end{array}$ & $\begin{array}{c}\text { ns } \\
p<0.01 \\
\text { ns } \\
\text { ns } \\
\text { ns } \\
\text { ns } \\
\text { ns } \\
\text { ns } \\
\text { ns } \\
\text { ns }\end{array}$ \\
\hline $\begin{array}{l}\text { Dialysis parameters } \\
\text { vascular access } \\
\text { arterio-venous fistula [n (\%)] } \\
\text { central venous catheter [n (\%)] } \\
\text { dialysis session duration }[\mathrm{h}] \\
\text { ultrafiltration [L] } \\
\text { residual diuresis }[\mathrm{mL}] \\
\text { residual diuresis > } 500 \mathrm{~mL} / \text { day }[\mathrm{n}(\%)]\end{array}$ & $\begin{array}{c}75(70.0) \\
32(29.9) \\
3.8 \pm 0.4 \\
2.5 \pm 0.9 \\
492 \pm 534 \\
31(29.0)\end{array}$ & $\begin{array}{c}22(66.7) \\
11(33.3) \\
3.8 \pm 0.5 \\
2.2 \pm 1.0 \\
597 \pm 535 \\
12(36.4)\end{array}$ & $\begin{array}{c}53(71.6) \\
21(28.4) \\
3.8 \pm 0.4 \\
2.6 \pm 0.8 \\
446 \pm 531 \\
19(25.7)\end{array}$ & $\begin{array}{c}\text { ns } \\
\text { ns } \\
\text { ns } \\
p<0.05 \\
\text { ns } \\
\text { ns }\end{array}$ \\
\hline $\begin{array}{l}\text { Pharmacotherapy } \\
\text { iron }[\mathrm{mg} / \text { week] } \\
\text { calcium carbonate }[\mathrm{g} / \text { day] } \\
\text { alfadiol }[\mathrm{n}(\%)] \\
\text { cinakalcet }[\mathrm{n}(\%)] \\
\text { sevelamer }[\mathrm{n}(\%)]\end{array}$ & $\begin{array}{c}33 \pm 40 \\
3.3 \pm 2.7 \\
36(33.6) \\
15(14.0) \\
3(2.8)\end{array}$ & $\begin{array}{l}35.6 \pm 41.5 \\
3.5 \pm 2.5 \\
9(27.3) \\
1(3.0) \\
0\end{array}$ & $\begin{array}{l}32.1 \pm 39.6 \\
3.3 \pm 2.8 \\
27(36.5) \\
12(16.2) \\
3(4.1)\end{array}$ & $\begin{array}{l}\text { ns } \\
\text { ns } \\
\text { ns } \\
\text { ns } \\
\text { ns }\end{array}$ \\
\hline $\begin{array}{l}\text { Biochemical parameters } \\
\text { phosphorus }[\mathrm{mg} / \mathrm{dL}] \\
\text { calcium }[\mathrm{mg} / \mathrm{dL}] \\
\text { poor serum calcium alignment [n (\%)] } \\
\text { iPTH }[\mathrm{pg} / \mathrm{mL}]\end{array}$ & $\begin{array}{c}5.8 \pm 1.5 \\
8.6 \pm 0.9 \\
2(1.9) \\
466 \pm 441\end{array}$ & $\begin{array}{c}4.3 \pm 0.5 \\
8.5 \pm 1.0 \\
0 \\
451 \pm 501\end{array}$ & $\begin{array}{c}6.5 \pm 1.3 \\
8.6 \pm 0.8 \\
2(2.7) \\
472 \pm 414\end{array}$ & $\begin{array}{c}\mathrm{p}<0.001 \\
\mathrm{~ns} \\
\mathrm{~ns} \\
\mathrm{~ns}\end{array}$ \\
\hline
\end{tabular}

BMI - body mass index; ADPKD - autosomal dominant polycystic kidney disease; $\mathrm{PCl}$ - percutaneous coronary intervention; CABG - coronary bypass grafting; iPTH - intact parathyroid hormone.

\section{Assessment of calcium-phosphate alignment}

The mean 6-month serum calcium and phosphorus levels in the study group were $8.6 \pm 0.9 \mathrm{mg} / \mathrm{dL}$ and $5.8 \pm 1.5 \mathrm{mg} / \mathrm{dL}$, respectively. Nearly $70 \%$ of patients $(n=74)$ had bad 
phosphate alignment ( $\geq 50 \%$ monthly phosphorus levels $\geq 5 \mathrm{mg} / \mathrm{dL}$; group B). Patients with good phosphate alignment (group A) were on average 8 years older than those with poorly controlled phosphate metabolism ( $\mathrm{p}<0.05$ ), and they were also characterized by a nearly 2 -fold shorter dialysis vintage and lower ultrafiltration ( $\mathrm{p}<0.005$ and $\mathrm{p}<0.05$, respectively). Both groups did not differ in the other assessed factors except bad calcium alignment, which occurred only in group B (Table 2).

\section{Macro- and micronutrient intake of HD patients in relation to the recommendations}

The intake of energy, and macro- and micronutrients in relation to the recommended values in HD patients is shown in Table 3. A high percentage of patients (80\%) had lower than recommended energy $(22.7 \pm 12.4 \mathrm{kcal} /$ $/ \mathrm{kg} /$ day) and fiber (14.2 $\pm 7.1 \mathrm{~g} /$ day $)$ intake. Almost two thirds of patients consumed less protein than is recommended $(0.9 \pm 0.5 \mathrm{~g} / \mathrm{kg} /$ day $)$. The majority of patients consumed more fat, sodium and calcium (33.5 $\pm 6.7 \%$;
$2912 \pm 1542 \mathrm{mg} /$ day; and $583 \pm 364 \mathrm{mg} /$ day, respectively) compared to recommendations. The average intake of phosphorus was $13.3 \pm 7.5 \mathrm{mg} / \mathrm{kg}$ body mass/day. Only in $40 \%$ of patients was the intake within the recommended range.

The degree of phosphorus alignment in relation to the intake of energy, macro- and micronutrients is shown in Table 4. The mean intake of protein and phosphorus in patients with good and bad phosphorus alignment did not differ significantly. High intake of protein $(>1.2 \mathrm{~g} / \mathrm{kg}$ body mass/day) resulted in a significant increase in phosphate intake ( $<$ < 0.05) (Fig. 2). However, protein intake $>1.2 \mathrm{~g} / \mathrm{kg}$ body mass/day did not increase the risk of phosphorus misalignment $(\mathrm{OR}=1.15$ [0.40-3.27]; $\mathrm{p}=0.8)$.

\section{Discussion}

Currently, there are 2 specific renal nutrition guidelines available for daily practice - the Clinical Practice Guidelines for nutrition in chronic renal failure, released in 2000 by NKF K/DOQI, and the more recent (2007) European

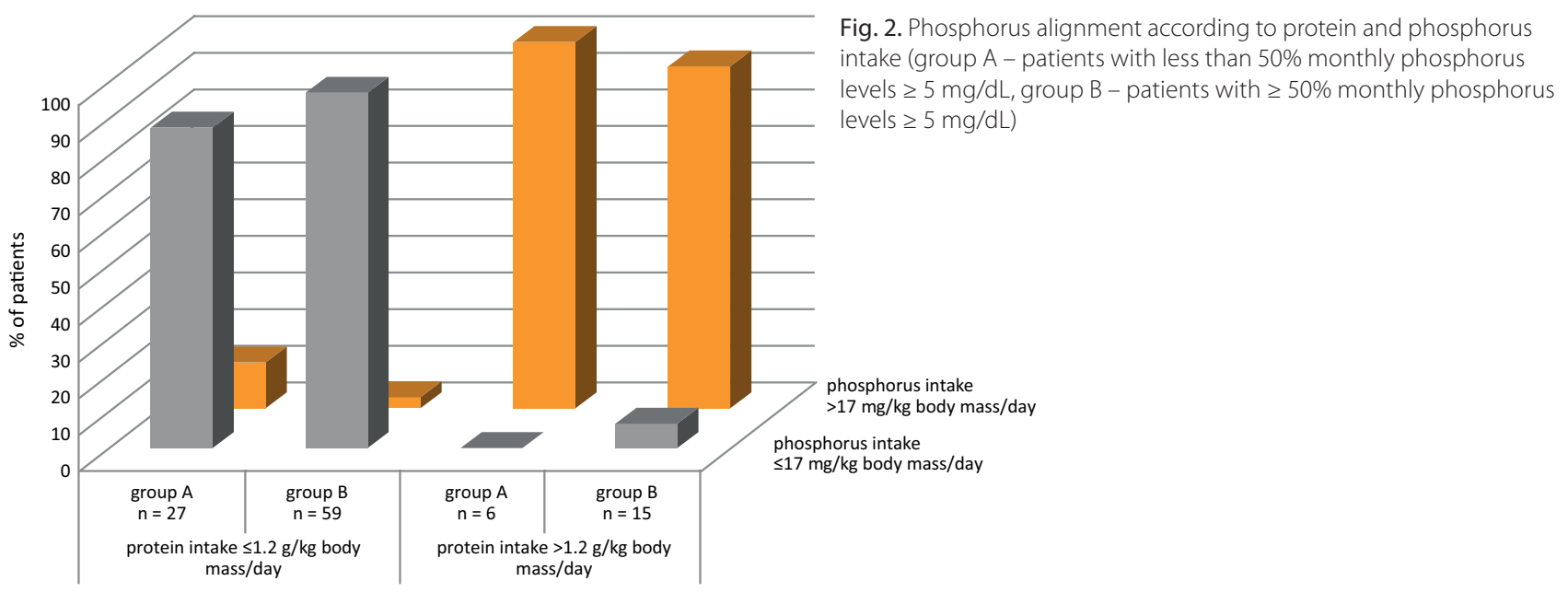

Table 3. Energy, macro- and micro-nutrient intake in 107 hemodialysis patient diets in comparison to K/DOQI recommendations

\begin{tabular}{|c|c|c|c|}
\hline \multirow{2}{*}{ Variable } & \multicolumn{3}{|c|}{$\%$ of patients } \\
\hline & below recommended level & according to recommendation & over recommended level \\
\hline Protein intake ${ }^{a}$ & 62.6 & 17.8 & 19.6 \\
\hline Energy intake & 82.8 & 9.5 & 7.6 \\
\hline Fat intake (\% of daily energy) ${ }^{b}$ & 10.3 & 16.8 & 72.9 \\
\hline Carbohydrate intake (\% of daily energy) ${ }^{c}$ & 24.3 & 74.7 & 0.9 \\
\hline Fiber intake & 81.3 & 13.0 & 5.6 \\
\hline Sodium & 3.7 & 26.1 & 70.0 \\
\hline Potassium & 65.4 & 10.3 & 24.3 \\
\hline Phosphorus & 34.6 & 42.0 & 23.4 \\
\hline Calcium & 0 & 18.6 & 81.4 \\
\hline Magnesium & 46.7 & 35.5 & 17.7 \\
\hline
\end{tabular}

${ }^{a}$ refers to $1.0-1.2 \mathrm{~g} / \mathrm{kg}$ body mass/day; ${ }^{\mathrm{b}}$ refers to $25-30 \%$ of daily energy intake; ${ }^{\mathrm{c}}$ refers to $45-75 \%$ of daily energy intake. 
Table 4. Energy, macro- and micronutrient intake in HD patients with good and bad phosphorus alignment

\begin{tabular}{|c|c|c|c|}
\hline Variable & Group A $(n=33)$ & Group B $(n=74)$ & p-value \\
\hline Protein intake (g/kg body mass/day) & $0.9 \pm 0.4$ & $0.9 \pm 0.6$ & ns \\
\hline Energy intake (kcal/kg body mass/day) & $23.8 \pm 12.4$ & $22.2 \pm 12.5$ & ns \\
\hline Fat intake (\% of daily energy) & $34.6 \pm 6.0$ & $33.1 \pm 7.0$ & ns \\
\hline Carbohydrate intake (\% of daily energy) & $50.6 \pm 7.2$ & $51.4 \pm 9.2$ & ns \\
\hline Dietary fiber intake (g/day) & $16.5 \pm 8.9$ & $13.1 \pm 6.0$ & $p=0.06$ \\
\hline Sodium intake (mg/day) & $3189 \pm 1619$ & $2789 \pm 1501$ & ns \\
\hline Potassium intake (mEq/day) & $68.5 \pm 34.6$ & $59.6 \pm 33.4$ & ns \\
\hline Phosphorus intake (mg/kg body mass/day) & $13.8 \pm 7.0$ & $13.1 \pm 7.7$ & ns \\
\hline Calcium intake (mg/day) & $4102 \pm 2454$ & $3809 \pm 2850$ & ns \\
\hline Magnesium intake (mg/day) & $247 \pm 129$ & $212 \pm 106$ & ns \\
\hline
\end{tabular}

Best Practice Guideline (EBPG) on Nutrition in Chronic Kidney Disease. ${ }^{11,12}$ It should be emphasized that there are several differences between those 2 documents (Table 1), and consensus has not been published yet.

There is limited data in the literature concerning nutrition knowledge and its adequacy to the nutritional recommendations in CKD patients in Poland, and they refer mostly to the non-dialysis population. ${ }^{13,14}$ One potential reason that could explain this fact is the difficulty in assessing the nutritional habits and diet of HD patients, mainly due to the need for precise recording of the size and type of food portions when using quantitative methods of diet assessment (a 24-hour diet interview or a 3-day food diary). Qualitative methods of diet assessment such as the DHQ-II questionnaire used in this study may be an alternative in the population of HD patients.

The unbalanced diet of dialysis patients may lead either to the shortage or the excess of specific nutrients. ${ }^{15}$ Proper energy intake in HD patients $(30 \mathrm{kcal} / \mathrm{kg}$ body mass/day for patients $\leq 60$ years of age, and $30-35 \mathrm{kcal} / \mathrm{kg}$ body mass/day for those over 60 years according to K/DOQI) is one of the determinants of normal nutritional status, and protects against malnutrition. In the present study, energy intake that was too low was the most common disorder seen in HD patients; it affected more than $80 \%$ of respondents. Similarly, energy intake that was too low was observed in 2 other studies using a 24-h diet interview in 92 and 38 Polish HD patients. ${ }^{16,17}$ Also in these studies, inadequate protein and fiber consumption was frequently observed. Recently, a paper by Luis et al. reported similar results for the Spanish population. Performing an analysis of 3-day dietary records of $91 \mathrm{HD}$ patients, they observed that only $11 \%$ and $15 \%$ of patients (based on K/DOQI guidelines and EBPG, respectively) fulfilled the recommended energy intake. This study also showed that a relatively low percentage of patients consumed enough protein and fiber ( $41 \%$ and $22 \%$, respectively). ${ }^{18}$ It is more difficult to increase the intake of fiber than of protein. The main sources of dietary fiber are fruits, vegetables, whole grains, and seeds. These sources are often rich also in potassium and phosphorus. However, a limited number of selected fruits (e.g., black currants, red currants, raspberries, white currants, and blackberries) and vegetables (e.g., green peas, broad beans, Brussels sprouts, and celeriac) should be more recommended than others to increase fiber intake (Table 5).

It should be emphasized that a significant association between the state of education concerning kidney diseases and its treatment (including the nutritional aspect), patient compliance and the number of complications (e.g., hyperphosphatemia) was observed. ${ }^{2,19}$ In the present study, we did not assess the level of patients' knowledge on diet recommendations specific for the HD population, nor the degree of compliance with the prescribed doses of phosphate-binding drugs, which is one of the limitations of the study.

Despite education regarding the need to limit dietary sources of phosphorus, and common use of phosphatebinding drugs, the percentage of HD patients diagnosed with hyperphosphatemia remains high. In a previously published study, we observed serum phosphorus levels exceeding $5.5 \mathrm{mg} / \mathrm{dL}$ in $56 \%$ of HD patients. ${ }^{20}$ In a recent epidemiological study that assessed the rank of calcium and phosphorus alignment among HD patients in Poland in the years 2003-2009, phosphorus concentrations higher than $6 \mathrm{mg} / \mathrm{dL}$ were observed in $51 \%$ of patients. ${ }^{21}$ With more stringent recommendations, consistent with current NKF K/DOQI criteria, the percentage of people characterized by poorly controlled serum phosphorus levels in the study group was significantly higher, as high as $69 \% .^{21}$

It is worth noting that the group with poorly controlled serum phosphorus concentration was significantly younger (on average by 8 years) compared to patients with good alignment, as in the previous study. ${ }^{20}$ Both groups had similar doses of oral phosphate binders prescribed, and phosphorus intake from protein. In addition, almost all patients with increased protein intake $(>1.2 \mathrm{~g} / \mathrm{kg}$ body mass $/$ day) consumed excessive amounts of phosphorus. Therefore, the reason for poor serum phosphorus alignment is rather related to the fact that inorganic phosphorus intake (i.e., beverages and highly processed foods) is greater in the younger population. 
Table 5. Amount of protein, phosphorous and potassium in fiber-rich fruits, vegetables and seeds (according to Polish tables of composition and nutritional value of food) ${ }^{23}$

\begin{tabular}{|c|c|c|c|c|}
\hline Variables & Dietary fiber $(\mathrm{g} / 100 \mathrm{~g})$ & Protein $(\mathrm{g} / 100 \mathrm{~g})$ & Potassium (mg/100 g) & $\begin{array}{l}\text { Phosphorus } \\
\text { (mg/100 g) }\end{array}$ \\
\hline \multicolumn{5}{|c|}{ Fruits } \\
\hline Dried figs & 12.9 & 3.6 & 938 & 122 \\
\hline Dried dates & 8.7 & 2.0 & 688 & 58 \\
\hline Black currants & 7.9 & 1.3 & 336 & 58 \\
\hline Red currants & 7.7 & 1.1 & 259 & 33 \\
\hline Raspberries & 6.7 & 1.3 & 203 & 33 \\
\hline Dried bananas & 6.4 & 3.8 & 1493 & 76 \\
\hline White currants & 6.4 & 1.0 & 275 & 23 \\
\hline Avocado & 3.3 & 2.0 & 600 & 41 \\
\hline Blackberries & 3.2 & 0.8 & 62 & 14 \\
\hline Gooseberries & 3.0 & 0.8 & 230 & 26 \\
\hline \multicolumn{5}{|c|}{ Vegetables } \\
\hline Soy (dry seeds) & 15.7 & 34.3 & 2132 & 743 \\
\hline White beans (dry seeds) & 15.7 & 21.4 & 1188 & 437 \\
\hline Peas (dry seeds) & 15.0 & 23.8 & 937 & 388 \\
\hline Red lentils (dry seeds) & 8.9 & 25.4 & 874 & 301 \\
\hline Horseradish & 7.3 & 4.5 & 740 & 120 \\
\hline Green peas & 6.0 & 6.7 & 353 & 122 \\
\hline Broad beans & 5.8 & 7.1 & 261 & 57 \\
\hline Brussels sprouts & 5.4 & 4.7 & 416 & 33 \\
\hline Parsley root & 4.9 & 2.6 & 399 & 77 \\
\hline Celeriac & 4.9 & 1.6 & 320 & 80 \\
\hline \multicolumn{5}{|c|}{ Seeds } \\
\hline Poppy seeds & 20.5 & 20.1 & 963 & 1022 \\
\hline Sesame seeds & 7.9 & 23.2 & 387 & 775 \\
\hline Sunflower seeds & 6.0 & 24.4 & 793 & 784 \\
\hline Pumpkin seeds & 5.3 & 24.5 & 810 & 1170 \\
\hline Flax seeds & 3.9 & 24.5 & 762 & 722 \\
\hline
\end{tabular}

It should be emphasized that the questionnaire used in the study did not take into account the intake of inorganic phosphates, which are often present in large amounts in highly processed foods, and account for a significant percentage of added preservatives (e.g., in meats or soft drinks). These products may be a source of the so-called 'hidden phosphorus', easily absorbed by the gastrointestinal tract. ${ }^{22}$ Therefore, in CKD patients the DHQ-II questionnaire cannot be the only tool used to assess phosphorus intake.

\section{Conclusions}

Adequate control of protein intake is not sufficient to obtain phosphorus alignment, especially in younger HD patients.

\section{References}

1. Da J, Xie X, Wolf M, Disthabanchong S, Wang J, Zha Y. Serum phosphorus and progression of CKD and mortality: A meta-analysis of cohort studies. Am J Kidney Dis. 2015;66:258-265.

2. Rutkowski B. National Consultant Board of and Expert Group. Statement of the National Consultant in Nephrology Board concerning education of nephrological patients. Nephrol Dial Pol. 2009;13: 116-118.

3. Dąbrowski P, Olszanecka-Glinianowicz M, Chudek J. Nutrition in chronic kidney disease. Endokrynol Otył Zab Przem Mat. 2011;7:229-237.

4. Kalantar-Zadeh K, Kopple JD. Nutritional management of maintenance hemodialysis patients. In: Kopple JD, Massry SG, Kalantar-Zadeh K, eds. Nutritional Management of Renal Diseases. Academic Press; 2013:503-538.

5. Palmer SC, Hanson CS, Craig JC, et al. Dietary and fluid restriction in CKD: A thematic synthesis of patient views from qualitative studies. Am J Kidney Dis. 2015;65:559-573.

6. Załuska W, Klinger M, Kusztal M, et al. Recommendations of the Working Group of the Polish Society of Nephrology for the criteria of quality treatment in dialysis patients with end-stage renal disease. Nephrol Dial Pol. 2015;1:6-11. 
7. Goldsmith DJ, Covic A, Fouque D, et al. Endorsement of the Kidney Disease Improving Global Outcomes (KDIGO) Chronic Kidney Disease-Mineral and Bone Disorder (CKD-MBD) Guidelines: A European Renal Best Practice (ERBP) commentary statement. Nephrol Dial Transplant. 2010;25:3823-3831.

8. National Kidney Foundation K/DOQI Clinical Practice Guidelines for Bone Metabolism and Disease in Chronic Kidney Disease. Am J Kidney Dis. 2003;42(Suppl 3):S1-S201.

9. Nowicki M, Rutkowski B, Myśliwiec M, Grenda R. Position Statement of the Polish Nephrology Consultants' Working Group on the diagnosis and treatment of chronic kidney disease-mineral and bone disorders. Nephrol Dial Pol. 2010;14(1);1-5.

10. Subar AF, Thompson FE, Kipnis V, et al. Comparative validation of the Block, Willett, and National Cancer Institute food frequency questionnaires: The Eating at America's Table Study. Am J Epidemiol. 2001; 154:1089-1099.

11. National Kidney Foundation K/DOQI Clinical Practice Guidelines for Nutrition in Chronic Renal Failure. Am J Kidney Dis. 2000;35(Suppl 2): S1-S140.

12. Fouque $D$, Vennegoor $M$, Ter Wee $P$, et al. EBPG guideline on nutrition. Nephrol Dial Transplant. 2007;22(Suppl 2):ii45-ii87.

13. Włodarek D, Głąbska D, Rojek-Trębicka J. Assessment of diet in chronic kidney disease female predialysis patients. Ann Agric Envirl Med. 2014;21:829-834.

14. Włodarek D, Głąbska D, Rojek-Trębicka J. Assesment of the nutritional knowledge, associated with low-protein diet following, on predialysis patients with chronic kidney disease. Nephrol Dial Pol. 2012; 16:11-14.
15. Rao P, Reddy GC, Kanagasabapathy AS. Malnutrition-inflammationatherosclerosis syndrome in chronic kidney disease. Indian J Clin Biochem. 2008;23:209-217.

16. Kardasz M, Małyszko J, Stefańska E, Ostrowska L. Assessment of dietary habits in hemodialysis and peritoneal dialysis patients. Przegl Lek. 2011;68:216-221.

17. Wyszomierska A, Puka J, Myszkowska-Ryciak J, Narojek L. The period of dialysis and nutritional habits of patients with the end stage renal disease. Rocz Panstw Zakl Hig. 2009;60:2289-2292.

18. Luis D, Zlatkis K, Comenge B, et al. Dietary quality and adherence to dietary recommendations in patients undergoing hemodialysis. J Ren Nutr. 2016;26:190-195.

19. Szurkowski M. The impact of personalized education on adherence to medical recommendations and effectiveness of treatment of calcium-phosphate disorders in patients with chronic renal failure undergoing chronic dialysis. Nephrol Dial Pol. 2015;19:32-39.

20. Wyskida K, Klein D, Sadowski L, et al. Factors affecting the poor phosphate control in hemodialysis patients with end stage chronic kidney disease. Nephrol Dial Pol. 2012;16:75-79.

21. Górski T, Biedunkiewicz B, Król E, Rutkowski P, Renke M, Rutkowski B. Epidemiology of calcium phosphate metabolism disturbances among dialysed patients in Poland in 2003-2006. Nephrol Dial Pol. 2015;19:55-59.

22. Fouque D, Horne R, Cozzolino M, Kalantar-Zadeh K. Balancing nutrition and serum phosphorus in maintenance dialysis. Am J Kidney Dis. 2014;64:143-150.

23. Kunachowicz H, Nadolna I, Iwanow K. Tabele składu i wartości odżywczej żywności. $1^{\text {st }}$ ed. Warszawa:Wydawnictwo LekarskiePZWL;2005:242-344. 